\title{
Ultrastructural and Cytochemical Investigations of the Antagonistic Effect of Verticillium lecanii on Cucumber Powdery Mildew
}

\author{
Hassan Askary, Nicole Benhamou, and Jacques Brodeur
}

First and third authors: Département de Phytologie, Centre de Recherche en Horticulture, Université Laval, Sainte-Foy, Québec, Canada G1K 7P4; second author: Département de Phytologie, Recherche en Sciences de la Vie et de la Santé, Pavillon C.E. Marchand, Université Laval, Sainte-Foy, Québec, Canada G1K 7P4.

Accepted for publication 6 December 1996.

\begin{abstract}
Askary, H., Benhamou, N., and Brodeur, J. 1997. Ultrastructural and cytochemical investigations of the antagonistic effect of Verticillium lecanii on cucumber powdery mildew. Phytopathology 87:359-368.

Chronological events of the intercellular interaction between Verticillium lecanii and cucumber powdery mildew, caused by Sphaerotheca fuliginea, were investigated at different times after inoculation by transmission electron microscopy. $V$. lecanii hyphae colonized host structures by tight binding, apparently mediated by a thin mucilaginous matrix. As early as $24 \mathrm{~h}$ after application of the antagonist, increased vacuolation and disorganization of the cytoplasm of the pathogen hyphae were easily detected. By $36 \mathrm{~h}$ after treatment, plasmalemma retraction and local cytoplasm aggregation were typical features of damage. Labeling chitin with the wheat germ agglutinin (WGA)/ovomucoid-gold complex showed that intracellular invasion of $S$. fuliginea by $V$. lecanii did not cause extensive host cell wall alterations, except in the area of hyphal penetration. By $48 \mathrm{~h}$ after inoculation, further cytoplasm disorganization was observed, as evidenced by the loss of cell turgor and contortion of the cell wall. Such deformation suggests that penetration of the antagonist results from mechanical pressure or localized enzymatic hydrolysis through the action of chitinases, as confirmed by the pattern of labeling obtained with the WGA/
\end{abstract}

ovomucoid-gold complex. By $72 \mathrm{~h}$ after contact between the fungi, $S$. fuliginea cells were markedly collapsed, depleted of their protoplasm due to extensive multiplication of the antagonist, and totally encircled by the antagonist. Based on the current observations, the antagonism of S. fuliginea by $V$. lecanii appears to involve the following events: (i) attachment of the antagonist to the powdery mildew fungus; (ii) mechanical pressure and production of cell-wall degrading enzymes such as chitinases; (iii) penetration and active growth of the antagonist inside the pathogen hyphae; and (iv) digestion of host tissues and release of the antagonist from dead cells of $S$. fuliginea. The interaction between $V$. lecanii and $S$. fuliginea also affected the morphological and structural features of the haustorial bodies, as shown by increased vacuolation, distortion, and necrotization of the haustorial lobes. These observations provide the first experimental evidence that $V$. lecanii, primarily known as an entomopathogenic fungus, also has the potential to colonize mycelial structures of S. fuliginea. V. lecanii, therefore, may become a valuable alternative to current management of cucumber powdery mildew in greenhouses.

Additional keywords: antibiosis, biological control, gold cytochemistry, hydrolytic enzymes, hyperparasitism.
The management of powdery mildews in greenhouse operations has become one of the most challenging research areas in plant pathology. In the past two decades, various measures have been recommended for controlling these diseases, including disinfestation of greenhouse structures and cultivation of resistant cultivars $(29,30)$. However, the wide host range of powdery mildew pathogens as well as their ability to proliferate abundantly under the favorable environmental conditions that usually prevail in greenhouses have markedly reduced the potential of such methods as management strategies. Chemicals such as sulfur, dinocap, and benomyl, as well as systemic fungicides, have been widely applied but have not always proved totally effective, at least at nonphytotoxic concentrations (7). In addition, increasing concern about both the environmental consequences of repeated fungicide applications and the rapid development of resistant fungal strains has limited the chemical options for control of powdery mildews $(15,34,36)$. Thus, in spite of much effort, powdery mildews remain a major problem for greenhouse producers worldwide. As a consequence, recent efforts have been directed primarily toward identifying new control measures that could be effective, reliable, and safe for the environment.

Corresponding author: J. Brodeur; E-mail address: jacques.brodeur@plg.ulaval.ca

Publication no. P-1997-0210-02R

(C) 1997 The American Phytopathological Society
One of the most promising approaches currently being explored is the use of biocontrol agents $(1,11)$. In the last few years, major developments in the biological control of several plant diseases have been achieved on an experimental, and in some cases a commercial, basis (9). Understandably, considerable attention has been paid to fungal antagonists because of their potential in reducing the inoculum density of pathogens (29). A number of fungi, such as Tilletiopsis yeasts $(25,27)$, Ampelomyces quisqualis (41), Stephanoascus spp. (anamorph Sporothrix spp.) (4,19,20), Aphanocladium album (29), and Paeciliomyces farinosus (29), have been reported to parasitize various powdery mildew pathogens and markedly reduce disease incidence. Another mycoparasite that is attracting attention because of its wide host range is Verticillium lecanii (A. Zimmerm.) Viégas. In recent years, this hyphomycete fungus has generated considerable commercial interest because of its potential as a powerful biopesticide $(22,23)$.

It has been shown convincingly that $V$. lecanii has the ability to control aphids and whiteflies, two of the most common greenhouse pests (22). The discovery that $V$. lecanii also could be an effective hyperparasite of several rust fungi, including Uromyces dianthi on carnation (38), U. appendiculatus on dwarf bean (17), and Puccinia recondita on wheat (39), as well as of some powdery mildew pathogens, such as Oidium tingtanium on citrus (33), Erysiphe graminis on barley (21), and Sphaerotheca fuliginea (Schlectend.:Fr.) Pollacci on cucumber $(40,43)$, has led to speculation about its development as a promising alternative to the use of 
fungicides on greenhouse crops. However, one prerequisite for rational utilization of the biological properties of a potential antagonist is an understanding of the mechanisms underlying the mycoparasitic process. Information such as host specificity, rate of potential colonization, as well as the relative importance of parasitism, competition, and antibiosis, is essential in planning an application strategy for practical biological control $(12,45)$.

In spite of extensive research on the utilization of $V$. lecanii for biological control of insects $(22,24)$, rust $(38,39)$, and powdery mildew fungi $(25,42,43)$, the exact mechanisms by which the parasitic process occurs are not fully understood. Although, some aspects of $V$. lecanii pathogenicity have been studied by light microscopy, little is known about the cellular events occurring during antagonistic relationships. To gain better insight into the mode of action of V. lecanii, the current study was undertaken to provide a detailed chronological picture of the interaction between this hyperparasite and cucumber powdery mildew caused by $S$. fuliginea.

\section{MATERIALS AND METHODS}

Fungal cultures and inoculation. Intensely colonized areas of cucumber leaves (Cucumis sativus L. 'Corona') naturally infected with $S$. fuliginea were cut into leaf disks $\left(40 \mathrm{~mm}^{2}\right)$. Four foliage disks were placed on moist filter paper in sterile petri dishes. $S$. fuliginea cultures used in the experiments were in culture for no longer than 8 days.

V. lecanii strain DAOM 198499 collected from codling moths, Cydia pomonella in Québec, was obtained from W. R. Jarvis, (Harrow Research Station Agriculture and Agrifood Canada, Ontario). The $V$. lecanii strain was grown in liquid aerobic cultures in nutrient medium YMPD (3 $\mathrm{g}$ of yeast extract, $3 \mathrm{~g}$ of malt, $5 \mathrm{~g}$ of peptone-water, and $10 \mathrm{~g}$ of dextrose per liter [Difco Laboratories, Detroit]). Conidial suspensions of the fungus were obtained from 4-day-old shake cultures by filtering the culture medium through cheesecloth for mycelial elimination. The resultant suspension was adjusted to $1 \times 10^{7}$ spores per ml. Cucumber leaf disks were sprayed to wetness by atomizing the conidial suspension of $V$. lecanii. For controls, infected leaf disks collected from the same plants were sprayed with sterile water. All petri dishes were air-dried, closed, and incubated at $22 \pm 1{ }^{\circ} \mathrm{C}, 95 \pm 2 \%$ relative humidity, under a 16:8 light/dark photoperiod.

Transmission electron microscopy (TEM) and cytochemical labeling of chitin ( $N$-acetylglucosamine). Samples $\left(1 \mathrm{~mm}^{2}\right)$ from both control and $V$. lecanii-treated cucumber leaf disks were collected 12, 24, 36, 48, and $72 \mathrm{~h}$ after inoculation. For each observation period, samples were taken from a minimum of four leaf disks to obtain a representative sampling of the interaction. Samples were immersed in $3 \%$ (vol/vol) glutaraldehyde in $0.1 \mathrm{M}$ sodium

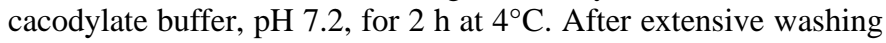
with the same buffer, samples were incubated for $1 \mathrm{~h}$ in $1 \%$ osmium tetroxide in the same buffer at $4^{\circ} \mathrm{C}$. Finally, the samples were dehydrated in a series of ethanol solutions graded in $10 \%$ steps and embedded in Epon 812. Ultrathin sections were mounted on Formvar-coated nickel grids and either contrasted with aqueous uranyl acetate and alkaline lead citrate for $10 \mathrm{~min}$ each or processed further for cytochemical labeling.

The colloidal gold suspension was prepared as described by Benhamou (5). To study the distribution of chitin (a linear polysaccharide of $\beta$-1,4-linked $N$-acetylglucosamine residues), wheat germ agglutinin (WGA) (Sigma Chemical Co., St. Louis), a lectin with $N$-acetylglucosamine-binding specificity (5), was used in a two-step procedure. Ovomucoid (Sigma), a high molecular-weight glycoprotein from egg white, was chosen (because of its specific binding affinity for WGA) as a second-step reagent and was complexed to colloidal gold at $\mathrm{pH} 5.4$ (5).

For cytochemical labeling, sections were incubated on a drop of phosphate-buffered saline (PBS), $\mathrm{pH} \mathrm{7.2,} \mathrm{for} 5 \mathrm{~min}$ and were transferred on a drop of WGA $(16 \mu \mathrm{g} / \mathrm{ml})$ in PBS, $\mathrm{pH} 7.2$, for 30 min at 23 to $24^{\circ} \mathrm{C}$ in a moist chamber. After being washed with PBS, the sections were incubated on gold-complexed ovomucoid (1:120 in PBS-polyethylene glycol) for $30 \mathrm{~min}$. Sections were washed with PBS, rinsed with distilled water, and contrasted with uranyl acetate and lead citrate. Samples were examined with a JEOL (Tokyo) 1200 EX transmission electron microscope with an accelerating voltage of $80 \mathrm{kV}$. To assess the specificity of labeling, sections were incubated on WGA previously adsorbed with $N-N^{\prime}-N^{\prime \prime}$-triacetylchitotriose and were transferred to the ovomucoid-gold complex.

\section{RESULTS}

Cytology of infection of cucumber leaves by $S$. fuliginea. $U l$ trastructural features and chitin distribution in S. fuliginea. Examination of transverse sections of mildewed cucumber leaves (control) revealed that $S$. fuliginea colonies were made up of dense, regularly septate mycelium (Fig. 1B). Hyphal cells were composed of a dense polyribosome-rich cytoplasm delimited by a thin, electron-lucent wall. Numerous organelles, including mitochondria, endoplasmic reticulum, nucleus, and vacuoles, were seen in the cytoplasm (Fig. 1A). After incubation with the WGA/ ovomucoid-gold complex, specific, regular deposition of gold particles was observed over the hyphal walls and septa, whereas cytoplasm and organelles were free of labeling (Fig. 1B). Previous adsorption of WGA with $N-N^{\prime}-N^{\prime \prime}$-triacetylchitotriose prior to section labeling resulted in an absence of labeling over both cell walls and septa (data not shown).

Ultrastructural features of haustorium formation in cucumber leaves infected by $S$. fuliginea. The cytology of infection by $S$. fuliginea resembled that previously described in a number of plants infected by biotrophic fungi $(18,32)$. Conidial germination at the leaf surface resulted in production of germ tubes that formed appressoria that firmly adhered to the cell surface. Successful host-wall penetration was associated with formation of narrow penetration pegs that crossed the cuticle and underlying epidermal cells. Enlargement of infection pegs in the epidermal cells resulted in elaboration of multilobed haustorial bodies (Fig. 1C). In transverse sections, the multishaped haustorial lobes appeared disconnected from each other (Fig. 1D). The haustorial cytoplasm contained numerous organelles, including elongated mitochondria (Fig. 1D). In all cases, the haustorial body was surrounded by a circonvoluted membrane - the extrahaustorial membrane-derived from the host plasma membrane. The extrahaustorial matrix was a network of intermingled fibrils surrounding the polymorphic lobes (Fig. 1D).

Ultrastructural features of the interaction between $V$. lecanii and $\boldsymbol{S}$. fuliginea at the cucumber leaf surface. As early as $24 \mathrm{~h}$ after application of the antagonist, the two fungi frequently were observed in close proximity (Fig. 2A). The antagonist was easily distinguished from the pathogen by its narrower hyphal diameter and its much more compact cytoplasm in which organelles were barely discernible (Fig. 2B). The average diameter of $V$. lecanii hyphae was estimated to be $1.5 \mu \mathrm{m}$, whereas those of $S$. fuliginea ranged between 10 and $15 \mu \mathrm{m}$. At this stage of the interaction, hyphae of the antagonist encircled cells of the pathogen without causing substantial deformations. Major cell changes were not observed, although examination of sections at high magnification revealed increased vacuolation that was often accompanied by disorganization of the cytoplasm (Fig. 2B), which appeared more granular than normal (Fig. 1A).

By $36 \mathrm{~h}$ after treatment with the antagonist, pathogen cell damage was more pronounced (Fig. 2C). Hyphae of S. fuliginea were markedly distorted, with plasmalemma retraction and local cytoplasm aggregation among the most typical features of pathogen cell reactions (Fig. 2C). However, some cells were even more intensely altered, as shown by the aspect of the cytoplasm that appeared reduced to electron-opaque strands of aggregated material in which vesicles were discernible (Fig. 2E). A close examination of the interfacial region revealed that the antagonist adhered to the 


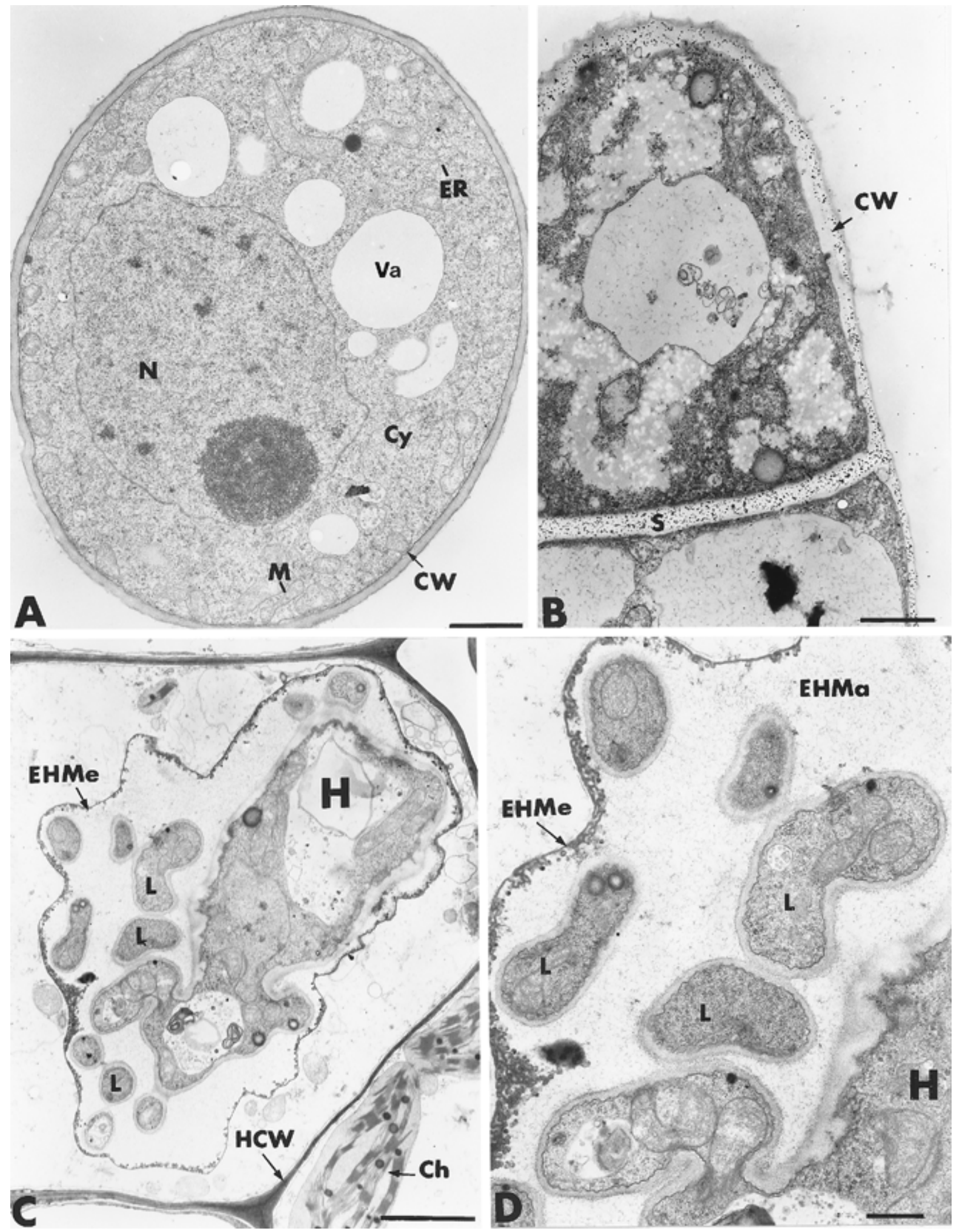

Fig. 1. Transmission electron micrographs of the interaction between cucumber leaf tissues and Sphaerotheca fuliginea. A and B, Ultrastructural aspect of $S$. fuliginea (A) and labeling of chitin with wheat germ agglutinin/ovomucoid-gold complex (B). Hyphal cells are composed of a dense polyribosome-rich cytoplasm (Cy) delimited by an electron-lucent cell wall (CW) and are septate (S). Numerous organelles including mitochondria (M), endoplasmic reticulum (ER), nucleus $(\mathrm{N})$, and vacuoles (Va) are seen in the cytoplasm. $\mathbf{A}, \times 8,000$, bar $=1 \mu \mathrm{m} . \mathbf{B}, \times 8,000$, bar $=1 \mu \mathrm{m}$. C and $\mathbf{D}$, Ultrastructural aspect of the haustorial body $(\mathrm{H})$ formed in the infected epidermal host cells. Multishaped haustorial lobes $(\mathrm{L})$ are disconnected from each other on transverse sections. The haustorial body is surrounded by a circonvoluted extrahaustorial membrane (EHMe). The extrahaustorial matrix (EHMa) is seen as a network of intermingled fibrils surrounding the polymorphic lobes. $\mathrm{Ch}=$ chloroplast; $\mathrm{HCW}=$ host cell wall. $\mathbf{C}, \times 6,500$, bar $=2 \mu \mathrm{m} . \mathbf{D}, \times 16,000$, bar $=0.5 \mu \mathrm{m}$. 


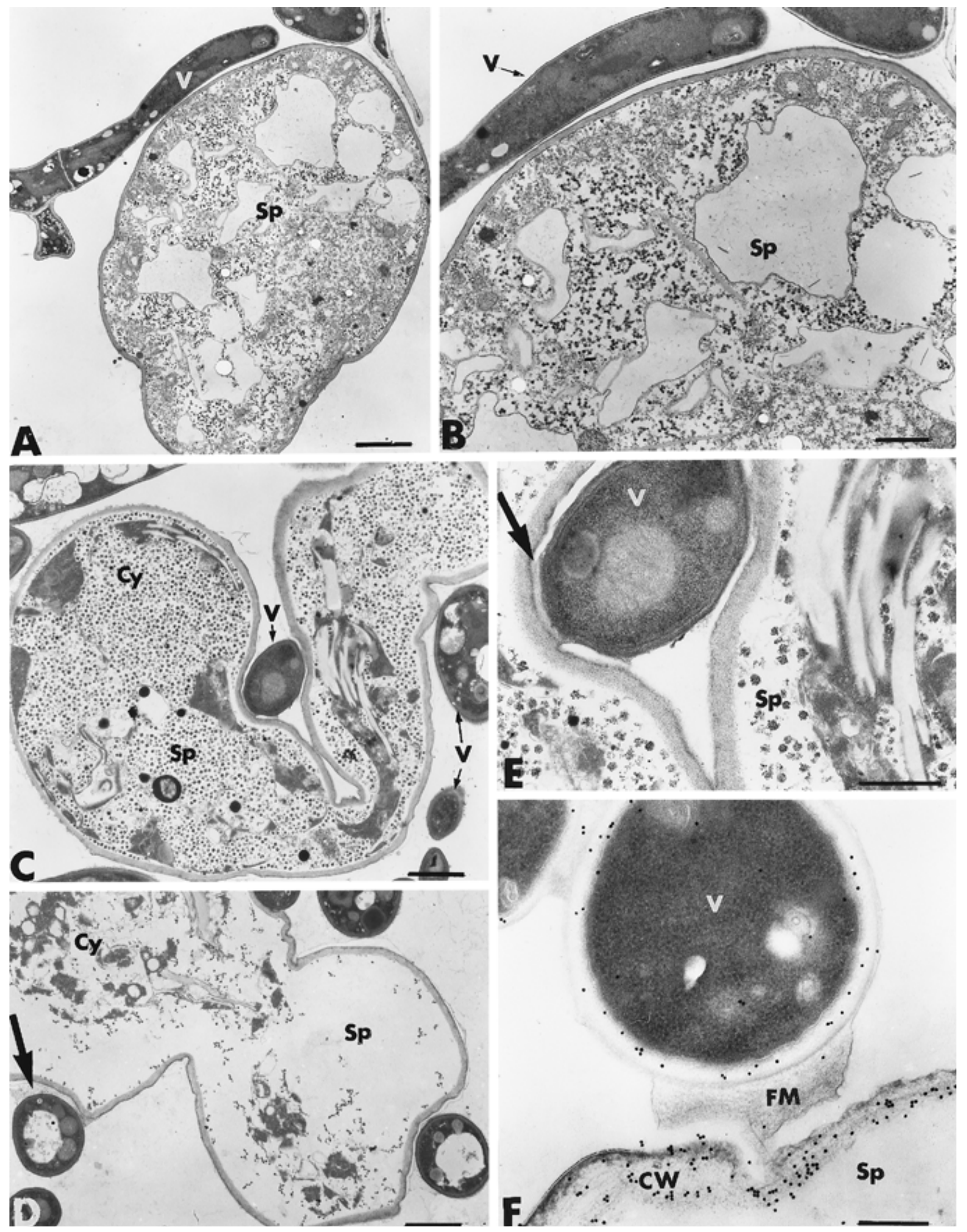

Fig. 2. Transmission electron micrographs of the interaction between cucumber leaf tissues and Sphaerotheca fuliginea (Sp) A and B, $24 \mathrm{~h}$ and $\mathbf{C}$ through F, $36 \mathrm{~h}$ after inoculation with Verticillium lecanii (V). A, Hyphae of the antagonist (V) encircle cells of the pathogen (Sp) without causing substantial deformations. $\times 4,000$, bar $=2 \mu \mathrm{m}$. B, At high magnification, increased vacuolation is seen accompanied by disorganization of the cytoplasm. $\times 8,000$, bar $=1 \mu \mathrm{m}$. $\mathbf{C}$, Hyphae of $S$. fuliginea are markedly distorted, as evidenced by plasmalemma retraction and local cytoplasm (Cy) aggregation. D, In some cases, cells are more intensely altered, as evidenced by the aspect of the cytoplasm reduced to electron-opaque strands of aggregated material. $\mathbf{C}$ and $\mathbf{D}, \times 8,000$, bar $=1 \mu \mathrm{m}$. $\mathbf{E}$, The antagonist (V) adheres to the host cells at the interfacial region (arrow) through a fibrillar matrix that is unlabeled by the wheat germ agglutinin/ovomucoid-gold complex. $\times 24,000$, bar $=0.5 \mu \mathrm{m} . \mathbf{F}$, In contrast, the pathogen cell wall $(\mathrm{CW})$ is labeled. $\mathrm{FM}=$ fibrillar matrix. $\times 40,000$, bar $=0.25 \mu \mathrm{m}$. 
cells through a fibrillar matrix that appeared to extend along the antagonist cell surface (Fig. 2D and E, arrows). When incubated with the WGA/ovomucoid-gold complex, the matrix was unlabeled, whereas gold particles were deposited over the walls of both fungi (Fig. 2F). Although the integrity of the pathogen cell wall appeared to be preserved compared to the cell content, observations at high magnification clearly showed that loosening of the fibrillar layers occurred (Fig. 2F).

By $48 \mathrm{~h}$ after inoculation with V. lecanii, S. fuliginea hyphae suffered from severe damage and no longer appeared to be viable (Fig. 3). Most cells had a markedly disorganized cytoplasm restricted to undefined masses varying in size and shape (Fig. 3B and C). Such cells usually were characterized by loss of turgor, as evidenced by pronounced contortion of the cell wall, leading to abnormally shaped hyphae (Fig. 3A). Cell invasion occurred through localized penetration of the distorted cell walls (Fig. 3C). Channels of penetration were always much narrower than the average hyphal diameter and usually were associated with little wall displacement in the growth direction (Fig. 3C, arrow). The loss of cell wall plasticity suggests that penetration resulted from mechanical pressure or localized enzymatic hydrolysis. This was confirmed by the observation that labeling of chitin still occurred over the walls and septa of parasitized S. fuliginea cells (Fig. 3D). Subsequent growth of the antagonist in the pathogen hyphae resulted, in most cases, in a complete loss of the previously altered protoplasm. The antagonist's cells developed abundantly in the host hyphae, and in this instance, a different pattern of host cell penetration was observed. Colonization of the host hyphae frequently resulted in strong mechanical pressure against the host cell walls and septa, ultimately leading to wall breakdown (Fig. 3D, double arrows).

By $72 \mathrm{~h}$ after contact between fungi, S. fuliginea cells were markedly collapsed (Fig. 4). Although in some cases aggregated cytoplasmic remnants could be seen (Fig. 4A), most cells were depleted of their protoplasm (Fig. 4B and C). At this stage, the antagonist multiplied extensively and totally encircled the plasmolyzed pathogen cells (Fig. 4D). Incubation with the WGA/ovomucoid-gold complex resulted in substantial deposition of gold particles over the convoluted walls of collapsed cells (Fig. 4C and D). However, close examination of these damaged fungal cells revealed the frequent occurrence of localized labeling disruptions, which were usually associated with the release of gold particles (Fig. 4C, arrow). In some cases, probably corresponding to a more advanced stage of interaction, labeling nearly disappeared over the entire cell walls of $S$. fuliginea hyphae, which were reduced to empty, undefined structures (Fig. 4E).

Effect of interaction between $V$. lecanii and $S$. fuliginea on formation of haustorial bodies. Although the antagonist was never detected in the cucumber leaf epidermis, changes in the morphological and structural features of the haustorial bodies were seen (Fig. 5). By $24 \mathrm{~h}$ after inoculation with V. lecanii, haustorial bodies apparently were preserved, although increased vacuolation of the haustorial lobes could be detected (Fig. 5A). By 36 to $48 \mathrm{~h}$ after contact between the fungi, the process of vacuolation increased further (Fig. 5B), often leading to the formation of apparently empty fungal cells surrounded by a thick wall specifically labeled by the WGA/ovomucoid-gold complex (Fig. 5C). Most haustorial bodies were severely damaged within $72 \mathrm{~h}$ after inoculation, with markedly distorted lobes. The degradation events were characterized primarily by necrotization of the fungal lobes, which appeared as aggregated, polymorphic structures lying in an amorphous matrix (Fig. 5D).

\section{DISCUSSION}

Since the initial demonstration that $V$. lecanii could be an effective hyperparasite of powdery mildews $(21,40)$, several investigators have suggested that this fungus has the potential to become a new class of biocontrol agents against one of the most important diseases of greenhouse-grown crops (43). However, in spite of increased interest in exploiting $V$. lecanii as a method for controlling powdery mildews, the exact mechanisms by which this mycoparasite operates have not been investigated fully. The results of the current study demonstrate that $V$. lecanii-inoculated cucumber leaves have increased resistance against the powdery mildew pathogen $S$. fuliginea and that this protection is associated with strong parasitic activity at the leaf cell surface. The beneficial effect of $V$. lecanii in reducing the rate and extent of pathogen colonization appears to be mediated by the production of antifungal substances prior to physical contact between the fungi, followed by cell-surface interaction between the two fungi and, finally, pathogen cell invasion.

TEM investigations of the cucumber leaf surface demonstrated that hyphae of $V$. lecanii developed abundantly, forming a dense mycelium that established close contact with both conidia and hyphae of the pathogen through a thin mucilaginous, extracellular matrix. This intimate contact between the fungi was associated with rapid collapse and loss of turgor of $S$. fuliginea cells. Pathogen cell damage was initiated in advance of intimate contact between both partners; the observation that $V$. lecanii hyphae were connected to cells of $S$. fuliginea through a fine matrix was taken as an indication that the outcome of the interaction was mediated, at least partly, by cell-surface events likely preceding penetration and invasion of the pathogen cells. Positive correlations between production of an extracellular sheath by $V$. lecanii and adhesion to the cuticle of insects have been reported (35). In such interactions, it has been suggested that the mucilage creates an environment promoting the activity of exocellular enzymes, which, in turn, display the ability to hydrolyze locally the insect cuticle, facilitating penetration and colonization of insect tissues. Although very little is known about the process leading to the invasion and development of $V$. lecanii in $S$. fuliginea, there is reason to assume that the interfacial material that forms between hyphae of the antagonist and cells of the pathogen mediates a specific recognition process, which, in turn, triggers a cascade of events, including host wall penetration and subsequent pathogen cell disintegration. Such a possibility has been raised in a number of other mycoparasitic interactions in which the saprophytic fungus Trichoderma harzianum, one of the most studied of the Trichoderma spp. identified for biological control, is involved $(9,13,14)$.

Several lines of evidence have shown that cell-surface molecules, including molecules with agglutinating properties such as lectins $(28,37)$, are important determinants in the mycoparasitic relationship between $T$. harzianum and various soilborne fungal pathogens $(2,6)$. Whether such a phenomenon occurs as a key event in the V. lecanii-S. fuliginea interaction warrants further investigation. However, the cytological observation that the binding of this material to the pathogen cell surface correlated with marked loosening of the fibrillar wall layers and a decrease in the chitin content in the contact areas (Fig. 2F) suggests that the secreted matrix favors the diffusion of enzymes involved in wall dissolution at sites of potential entry. Because similar production of material was not seen in single cultures of V. lecanii (H. Askary, N. Benhamou, and J. Brodeur, unpublished data), it seems reasonable to speculate that molecular signaling between the two partners may be responsible for the observed response.

According to our cytological observations, the process of $S$. fuliginea colonization by $V$. lecanii involved a sequence of events, including (i) attachment, local penetration, and active multiplication of the antagonist in conidia and hyphae of the pathogen and (ii) release of the antagonist through moribund hyphal cells. One of the most typical features of this antagonistic process was the series of events that took place prior to contact between both fungi. The exact mechanisms by which the antagonist specifically affected the pathogen at a distance are unknown, but it is likely that they derive from a complex strategy involving production and 
diffusion of antifungal metabolites. Although we cannot exclude the possibility that parasitism at another part of the hyphal strand may have resulted in the observed effect, our observations of a large number of sections suggest that hyphae of the pathogen un- derwent marked disorganization at a time when strict parasitism did not yet occur. A similar phenomenon has been reported often in other antagonistic interactions and described as a process of antibiosis involving rapid diffusion of toxic metabolites that cor-
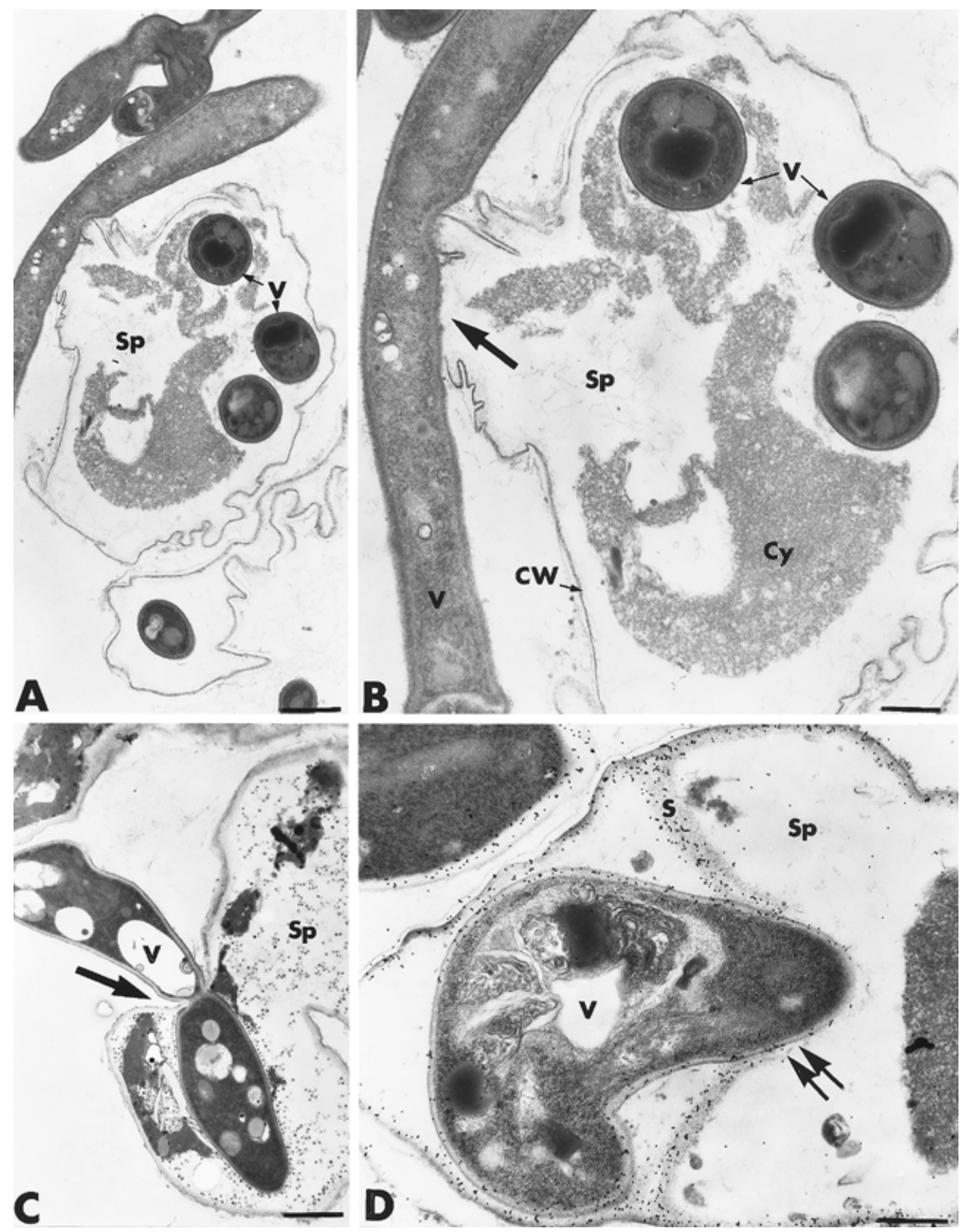

Fig. 3. Transmission electron micrographs of the interaction between cucumber leaf tissues and Sphaerotheca fuliginea (Sp) $48 \mathrm{~h}$ after inoculation with Verticillium lecanii (V). A and B, Disorganized cytoplasm (Cy) of the pathogen (Sp) is restricted to undefined masses of granular material. Such cells are characterized by their loss of turgor, as evidenced by the pronounced contortion of the cell wall (CW), which in places is in close contact with the antagonist (V) (B, arrow). Cells of the antagonist are seen inside hyphae of the pathogen $(\mathrm{Sp}) . \mathbf{A}, \times 8,000$, bar $=1 \mu \mathrm{m} . \mathbf{B}, \times 16,000$, bar $=0.5 \mu \mathrm{m}$. $\mathbf{C}$, Pathogen $(\mathrm{Sp})$ cell penetration by means of constricted hyphae of the antagonist $(\mathrm{V})$ is seen (arrow). $\times 8,000$, bar $=1 \mu \mathrm{m}$. D, Colonization of the host hyphae occurs through mechanical pressure against the host septa (double arrows). $\mathrm{S}=$ septum. $\times 19,000$, bar $=0.5 \mu \mathrm{m}$. 

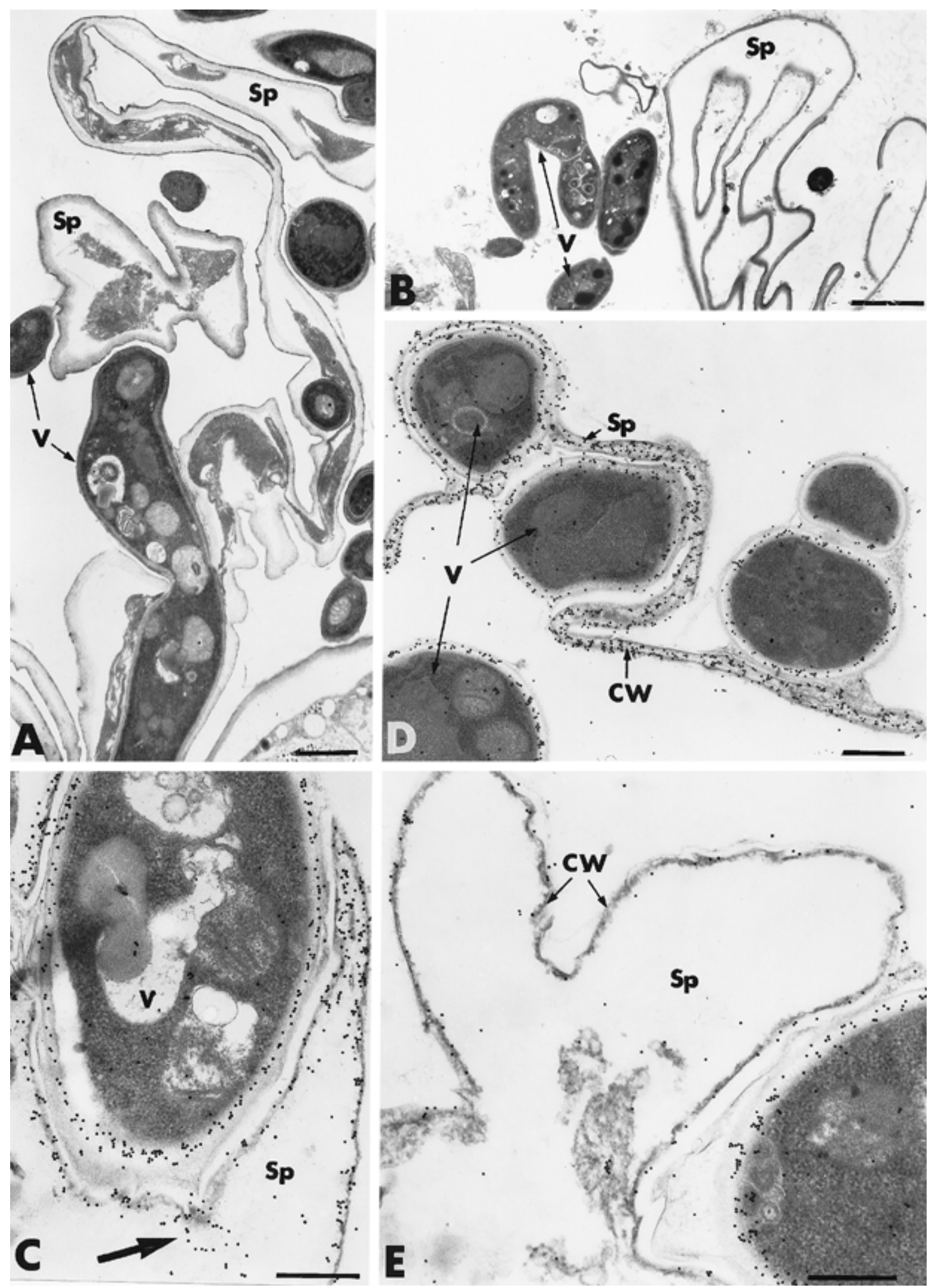

Fig. 4. Transmission electron micrographs of the interaction between cucumber leaf tissues and Sphaerotheca fuliginea (Sp) $72 \mathrm{~h}$ after inoculation with Verticillium lecanii $(\mathrm{V})$. A and B, Cells of S. fuliginea are markedly collapsed $(\mathbf{A})$ or even depleted of their protoplasm $(\mathbf{B}) . \mathbf{A}, \times 8,000$, bar $=1 \mu \mathrm{m} . \mathbf{B}, \times 5,000$, bar $=$ $2 \mu \mathrm{m}$. C and D, Incubation with wheat germ agglutinin/ovomucoid-gold complex results in intense, regularly distributed labeling over convoluted walls (CW) of collapsed pathogen cells. In some cases, labeling may be locally disrupted, as evidenced by the release of gold particles $(\mathrm{C}$, arrow). $\mathrm{C}, \times 32,000$, bar $=$ $0.25 \mu \mathrm{m}$. D, $\times 24,000$, bar $=0.5 \mu \mathrm{m}$. E, At a more advanced stage of the antagonist-pathogen interaction, labeling nearly disappears over the entire pathogen cell walls. $\times 32,000$, bar $=0.25 \mu \mathrm{m}$. 
relate with major structural changes, such as plasmalemma retraction and cytoplasm aggregation $(3,19,20,31)$. Similar cellular disturbances have been reported often in the case of fungal cells exposed to fungicides (26).
It has been postulated that changes in the lipid and phospholipid composition of the fungal plasma membrane induce alterations in membrane permeability, promoting internal osmotic imbalances and leading to plasmolysis (44). In addition to the typical struc-

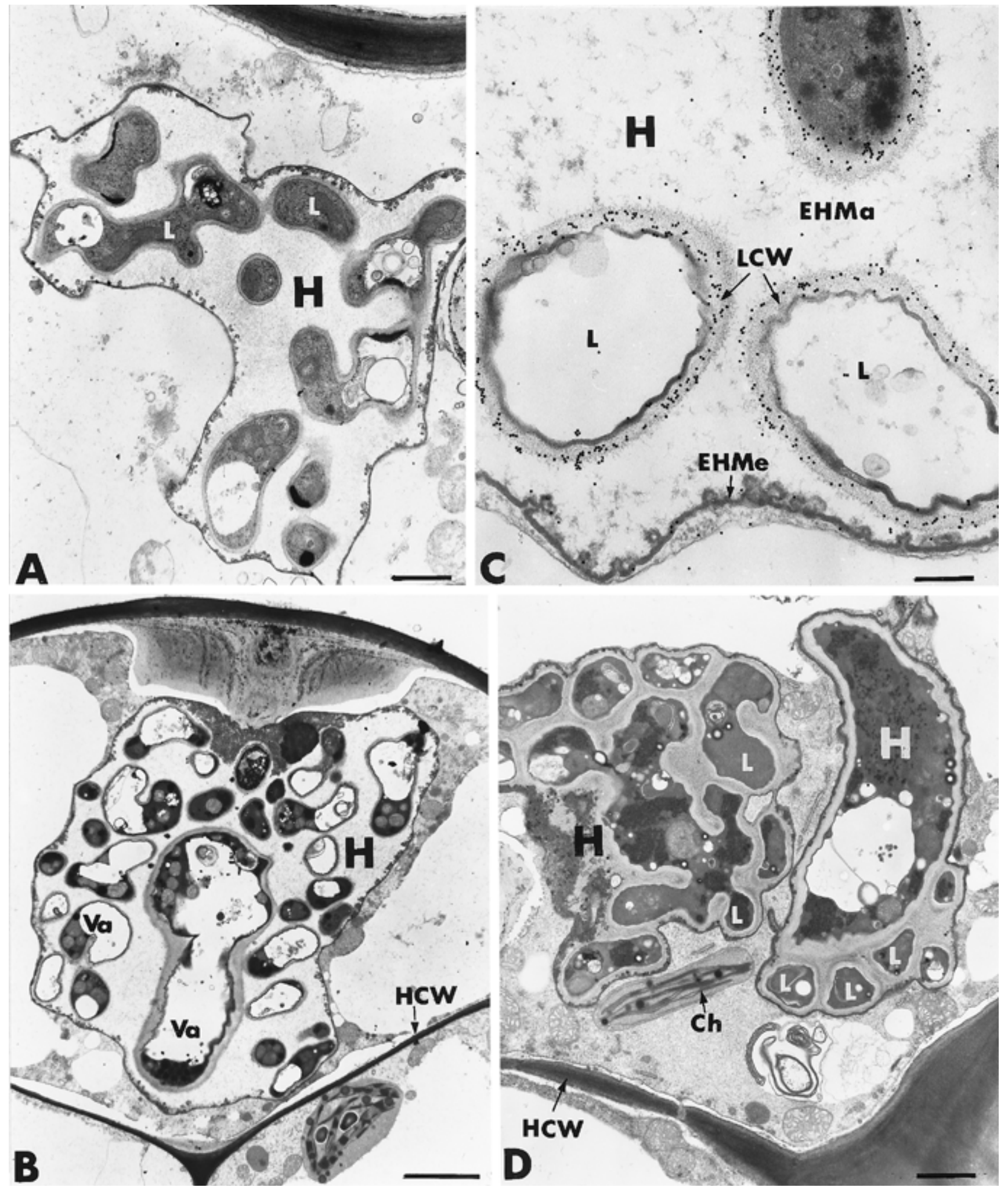

Fig. 5. Transmission electron micrographs of the interaction between cucumber leaf tissues and Sphaerotheca fuliginea A, 24 h, B and C, 36 to 48 h, and D, $72 \mathrm{~h}$ after inoculation with Verticillium lecanii. A, The haustorial body $(\mathrm{H})$ is apparently preserved, although increased vacuolation of the haustorial lobes (L) is seen. $\times 8,000$, bar $=1 \mu \mathrm{m}$. B and $\mathbf{C}$, The process of vacuolation (Va) increases further $(\mathbf{B})$, leading to the formation of apparently empty haustorial lobes surrounded by a thick wall $(\mathrm{LCW})$ labeled by the wheat germ agglutinin/ovomucoid-gold complex $(\mathbf{C})$. EHMa = extrahaustorial matrix; EHMe = extrahaustorial membrane; $\mathrm{HCW}=$ host cell wall. $\mathbf{B}, \times 32,000$, bar $=0.25 \mu \mathrm{m} . \mathbf{C}, \times 4,800$, bar $=2 \mu \mathrm{m}$. D, The haustorial body is severely damaged and the haustorial lobes are markedly distorted and necrotized. $\mathrm{Ch}=$ chloroplast. $\times 8,000, \mathrm{bar}=1 \mu \mathrm{m}$. 
tural changes observed, another argument that reinforces the implication of toxic metabolites as an early step in the antagonistic process between $V$. lecanii and $S$. fuliginea comes from the welldocumented ability of $V$. lecanii to secrete toxins with insecticidal properties $(10,16)$. Although it remains to be demonstrated that such metabolites also have a deleterious effect on pathogenic fungi such as $S$. fuliginea, our observations indicate that antibiosis causing cytoplasm disintegration precedes parasitism and subsequent internal colonization of $S$. fuliginea cells. One may presume that weakened or dead cells of the pathogen are invaded more easily by hyphae of the antagonist, which then may find sufficient nutrients to stimulate their growth and multiplication.

Growth of V. lecanii toward cells of S. fuliginea was followed by hyphal adhesion and intracellular invasion. Successful penetration of the host cell wall by the antagonist was achieved frequently, indicating that at least small amounts of cell wall hydrolytic enzymes such as chitinases were produced by the antagonist to locally weaken or loosen the host cell wall. In all examined samples, hyphal penetration of the antagonist into cells of $S$. fuliginea was seldom associated with extensive host cell wall alterations. This was corroborated by the pattern of labeling obtained with the WGA/ovomucoid-gold complex, which showed that, except in the area of hyphal penetration, the chitin component of the host cell walls was preserved structurally at a time when the host cytoplasm had undergone pronounced disorganization. These observations indicated that production of cell-wall degrading enzymes by $V$. lecanii likely occurred but was not the first event involved in pathogen breakdown, as has been suggested often for Trichoderma spp. (14). The production of extracellular lytic enzymes by $V$. lecanii is a phenomenon involved in the process of insect cuticle penetration $(8,35)$. In contrast, little information is available on the role played by hydrolytic enzymes in the interactions between this antagonist and pathogenic fungi, even though digested areas at sites of rust spore penetration have been described by Spencer and Atkey (39). Although it is clear that enzymes produced by $V$. lecanii play an important role in breaching the host cell walls at sites of attempted penetration, it seems likely that further enzymatic production contributes more to the saprophytic phase of the antagonist when the cell content is utilized as a nutrient source providing the energy required to multiply actively (Fig. 3D). The observation that wall displacement and, in some cases, wall and septum distortion correlated with cell invasion by the antagonist indicated that a combination of physical and chemical factors was involved in cell wall penetration.

Based on the current observations, the antagonism of S. fuliginea by $V$. lecanii appears to follow a specific sequence of events, including (i) attachment of the antagonist to the powdery mildew fungus, (ii) mechanical pressure and production of cell wall-degrading enzymes such as chitinases, (iii) penetration and active growth of the antagonist inside the pathogen hyphae, and (iv) digestion of host tissues and release of the antagonist from dead cells of $S$. fuliginea. This sequence of events, which occurs at the cucumber leaf surface, greatly affected the haustorial structures and even prevented their formation. Although cells of $V$. lecanii were unable to penetrate the plant epidermis, our time-course investigation revealed that a series of changes ranging from increased vacuolation to complete necrotization of the haustorial lobes was a typical feature of reaction to treatment with the antagonist. Whether such an haustorial alteration was a logical consequence of the extensive degradation of the powdery mildew fungal hyphae at the cell surface or derived from the action of toxic compounds released by the antagonist remains to be determined.

Whatever the mechanisms underlying these degradation events, the current results clearly demonstrate that $V$. lecanii acts through a strong antagonistic activity that adversely affects the formation and biological function of haustoria. These observations provide the first convincing evidence that $V$. lecanii, primarily known as an entomopathogenic fungus (22), also has the potential to be- come an effective biocontrol agent of cucumber powdery mildew. However, it is important to mention that the results reported here were obtained on detached leaves maintained under controlled conditions. It will now be necessary to investigate whether the antagonistic process recorded under this experimental situation occurs on cucumber plants in the greenhouse.

\section{ACKNOWLEDGMENTS}

This work was supported by grants from the National Sciences and Engineering Research Council of Canada to J. Brodeur and N. Benhamou and the Conseil des Recherches en Pêche et en Agro-Alimentaire du Québec to J. Brodeur. We thank W. R. Jarvis (Harrow Research Station, Agriculture and Agrifood Canada, Ontario) for the $V$. lecanii strain and S. Noël for excellent technical assistance.

\section{LITERATURE CITED}

1. Baker, K. F., and Cook, R. J. 1974. Biological Control of Plant Pathogens. W. H. Freeman Co., San Francisco.

2. Barak, R., Elad, Y., Mirelman, D., and Chet, I. 1985. Lectins: A possible basis for specific recognition in the interaction of Trichoderma and Sclerotium rolfsii. Phytopathology 75:458-462.

3. Bélanger, R. R., Dufour, N., Caron, J., and Benhamou, N. 1995. Chronological events associated with the antagonistic properties of Trichoderma harzianum against Botrytis cinerea: Indirect evidence for sequential role of antibiosis and parasitism. Biocontrol Sci. Technol. 5:41-53.

4. Bélanger, R. R., Labbé, C., and Jarvis, W. R. 1994. Commercial-scale control of rose powdery mildew with a fungal antagonist. Plant Dis. 78:420424.

5. Benhamou, N. 1989. Preparation and application of lectin-gold complexes. Pages 95-143 in: Colloidal Gold, Principles, Methods, and Application. Vol. 1. M. A. Hayat, ed. Academic press, New York.

6. Benhamou, N., and Chet, I. 1993. Hyphal interactions between Trichoderma harzianum and Rhizoctonia solani: Ultrastructure and gold cytochemistry of the mycoparasitic process. Phytopathology 83:1062-1071.

7. Bent, K. J. 1978. Chemical control of powdery mildews. Pages 259-282 in: The Powdery Mildews. D. M. Spencer, ed. Academic Press, London.

8. Butt, T. M. 1990. Fungal infection processes-A mini-review. Pages 121-124 in: 5th Int. Colloq. Invertebr. Pathol. Microbial Control. Society for Invertebrate Pathology, Adelaide, Australia.

9. Chet, I. 1987. Trichoderma-Application, mode of action, and potential as a biocontrol agent of soilborne plant pathogenic fungi. Pages 137-160 in: Innovative Approaches to Plant Disease Control. I. Chet, ed. John Wiley \& Sons, New York.

10. Clydon, N., and Grove, J. F. 1982. Insecticidal secondary metabolic products from the entomogenous fungus Verticillium lecanii. J. Invertebr. Pathol. 40:413-418.

11. Cook, R. J., and Baker, K. F. 1983. The Nature and Practice of Biological Control of Plant Pathogens. The American Phytopathological Society, St. Paul, MN.

12. Deacon, J. W., and Berry, L. A. 1992. Mode of action of mycoparasites in relation to biocontrol of soilborne plant pathogens. Pages 157-167 in: Biological Control of Plant Diseases. E. C. Tjamos, G. C. Papavizas, and R. J. Cook, eds. Plenum Press, New York.

13. Elad, Y., Chet, I., and Henis, Y. 1982. Degradation of plant pathogenic fungi by Trichoderma harzianum. Can. J. Microbiol. 28:719-725.

14. Elad, Y., Hadar, Y., Chet, I., and Henis, Y. 1982. Prevention with Trichoderma harzianum Rifai aggr., of reinfestation by Sclerotium rolfsii Sacc. and Rhizoctonia solani Kühn of soil fumigated with methyl bromide and improvement of disease control in tomatoes and peanuts. Crop Prot. 1: 199-211.

15. Fletcher, J. T. 1984. Diseases of Greenhouse Plants. Longman, London.

16. Gindin, G., Barash, I., Harari, N., and Raccah, B. 1994. Effect of endotoxic compounds isolated from Verticillium lecanii on the sweetpotato whitefly, Bemisia tabaci. Phytoparasitica 22:189-196.

17. Grabski, G. C., and Mendgen, K. 1986. Die parasitierung des bohnenrostes Uromyces appendiculatus var. appendiculatus durch den hyperparasiten Verticillium lecanii: Untersuchungen zur wirt-erkennung, penetration und abbau der rostpilzsporen. J. Phytopathol. 115:116-123.

18. Hajlaoui, M. R., and Bélanger, R. R. 1991. Comparative effects of temperature and humidity on the activity of three potential antagonists of rose powdery mildew. Neth. J. Plant Pathol. 97:203-208.

19. Hajlaoui, M. R., and Bélanger, R. R. 1993. Antagonism of the yeast-like phylloplane fungus Sporothrix flocculosa against Erysiphe graminis var. tritici. Biocontrol Sci. Technol. 3:427-434.

20. Hajlaoui, M. R., Benhamou, N., and Bélanger, R. R. 1992. Cytochemical 
study of the antagonistic activity of Sporothrix flocculosa on rose powdery mildew, Sphaerotheca pannosa var. rosae. Phytopathology 82:583589.

21. Hall, R. A. 1980. Laboratory infection of insects by Verticillium lecanii strains isolated from phytopathogenic fungi. Trans. Br. Mycol. Soc. 74: 445-446.

22. Hall, R. A. 1981. The fungus Verticillium lecanii as a microbial insecticide against aphids and scales. Pages 483-498 in: Microbial Control of Pests and Plant Diseases. H. D. Burges, ed. Academic Press, London.

23. Hall, R. A., and Burges, H. D. 1979. Control of aphids in glasshouses with the fungus, Verticillium lecanii. Ann. Appl. Biol. 93:235-246.

24. Harper, A. M., and Huang, H. C. 1986. Evaluation of the entomophagous fungus Verticillium lecanii (moniliales: Moniliaceae) as a control agent for insects. Environ. Entomol. 15:281-284.

25. Hijwegen, T. 1988. Effect of seventeen fungicolous fungi on sporulation of cucumber powdery mildew. Neth. J. Plant Pathol. 94:185-190.

26. Hippe, S. 1991. Influence of fungicides on fungal fine structure. Pages 307-331 in: Electron Microscopy of Plant Pathogens. K. Mendgen and D. E. Lesemann, eds. Springer-Verlag, Berlin.

27. Hoch, H. C., and Provvidenti, R. 1979. Mycoparasitic relationships: Cytology of the Sphaerotheca fuliginea-Tilletiopsis sp. interaction. Phytopathology 69:359-362.

28. Inbar, J., and Chet, I. 1994. A newly isolated lectin from the plant pathogenic fungus Sclerotium rolfsii: Purification, characterization and role in mycoparasitism. J. Gen. Microbiol. 140:651-657.

29. Jarvis, W. R. 1992. Managing Diseases in Greenhouse Crops. The American Phytopathological Society, St. Paul, MN.

30. Jarvis, W. R., Shaw, L. A., and Traquair, J. A. 1989. Factors affecting antagonism of cucumber powdery mildew by Stephanoascus flocculosus and S. rugulosus. Mycol. Res. 92:162-165.

31. Klecan, A. L., Hippe, S., and Somerville, S. C. 1990. Reduced growth of Erysiphe graminis f. sp. hordei induced by Tilletiopsis pallescens. Phytopathology 80:325-331.

32. Manners, J. M., and Gay, J. L. 1977. The morphology of haustorial com- plexes isolated from apple, barley, beet and vine infected with powdery mildews. Physiol. Plant Pathol. 11:261-266.

33. Raghavendra Rao, N. N., and Pavgi, M. S. 1977. Two mycoparasites on powdery mildews. Sydowia 30:145-147.

34. Schepers, H. T. A. M. 1983. Decreased sensitivity of Sphaerotheca fuliginea to fungicides which inhibit ergosterol biosynthesis. Neth. J. Plant Pathol. 89:185-187.

35. Schreiter, G., Butt, T. M., Beckett, A., Vestergaard, S., and Moritz, G. 1994. Invasion and development of Verticillium lecanii in the western flower thrips, Frankliniella occidentalis. Mycol. Res. 98:1025-1034.

36. Schroeder, W. T., and Provvidenti, R. 1969. Resistance to benomyl in powdery mildew of cucurbits. Plant Dis. Rep. 53:271-275.

37. Sequeira, L. 1985. Surface components involved in bacterial pathogenplant host recognition. J. Cell Sci. Suppl. 2:301-316.

38. Spencer, D. M. 1980. Parasitism of carnation rust (Uromyces dianthi) by Verticillium lecanii. Trans. Br. Mycol. Soc. 74:191-194.

39. Spencer, D. M., and Atkey, P. T. 1981. Parasitic effects of Verticillium lecanii on two rust fungi. Trans. Br. Mycol. Soc. 77:535-542.

40. Spencer, D. M., and Ebben, M. H. 1981. Biological control of powdery mildew. Pages 128-129 in: Annual Report of the Glasshouse Crops Research Institute, Littlehampton, Sussex, United Kingdom.

41. Sundheim, L. 1982. Control of cucumber powdery mildew by the hyperparasite Ampelomyces quisqualis and fungicides. Plant Pathol. 31:209-214.

42. Verhaar, M. A., and Hijwegen, T. 1993. Efficient production of phialoconidia of Verticillium lecanii for biocontrol of cucumber powdery mildew, Sphaerotheca fuliginea. Neth. J. Plant Pathol. 99:101-103.

43. Verhaar, M. A., Hijwegen, T., and Zadoks, J. C. 1996. Glasshouse experiments on biocontrol of cucumber powdery mildew (Sphaerotheca fuliginea) by the mycoparasites Verticillium lecanii and Sporothrix rugulosa. Biol. Control 6:353-360.

44. Weete, J. 1980. Lipid Biochemistry of Fungi and Other Organisms. Plenum Press, New York.

45. Whipps, J. M. 1992. Status of biological disease control in horticulture. Biocontrol Sci. Technol. 2:3-24. 